Check for updates

Cite this: RSC Adv., 2018, 8, 39870

\title{
A novel approach to iron oxide separation from e- waste and bisphenol A detection in thermal paper receipts using recovered nanocomposites $\uparrow$
}

\author{
Muthumariappan Akilarasan, $\ddagger^{a}$ Sakthivel Kogularasu, $t^{a}$ Shen-Ming Chen, (D) *a \\ Tse-Wei Chen ${ }^{a}$ and Bih-Show Lou*bc
}

\begin{abstract}
To promote sustainability, the effective reutilization of electronic waste and profitable recovery of valuable materials from e-scrap are essential. A recent report showed that 500 million printer cartridges enter landfill annually, creating immense interest in establishing a facile recovery method for transforming waste toner into a ferrous resource. Furthermore, the European Union and US Food and Drug Administration have published guidelines concerning bisphenol A (BPA) use in the manufacture of thermal paper receipts. Accordingly, in this study, BPA levels in thermal receipts collected from various stores in Taiwan were detected by glassy carbon electrodes fabricated using graphene oxide-recovered $\mathrm{Fe}_{3} \mathrm{O}_{4}$ nanocomposites.
\end{abstract}

Received 27th September 2018 Accepted 8th November 2018

DOI: $10.1039 / \mathrm{c} 8 \mathrm{ra0} 0017 \mathrm{~h}$

rsc.li/rsc-advances

following a prolonged study on BPA toxicity, in February 2018 the European Union and US Food and Drug Administration (FDA) publishing guidelines to prohibit BPA use as a component in thermal paper manufacture. ${ }^{19-22}$ Accordingly, our research group collected thermal receipt paper from various stores in Taiwan, including 7-Eleven, Family Mart, PX Mart, OK Mart, Hi-Life, and KFC, as well as ATM receipts, to determine their constituent BPA levels. A standardized HPLC-UV detection method was used to detect the BPA levels in thermal receipt samples prepared using migration and digestion techniques. Surprisingly, high BPA levels were found in the collected thermal receipts. This inspired our research group to establish a trace level BPA detector. Recently, $\mathrm{Fe}_{3} \mathrm{O}_{4}$ was reported as an active participant in the selective detection of BPA, ${ }^{23,24}$ while graphene oxide (GO) sheets have also been shown to improve the sensing capability of BPA detection..$^{25,26}$

Herein, $\mathrm{Fe}_{3} \mathrm{O}_{4}$ nanoparticles recovered from toner were sonicated with $\mathrm{GO}$ nanosheets to obtain a $\mathrm{GO}-\mathrm{Fe}_{3} \mathrm{O}_{4}$ composite, which was then fabricated onto a glassy carbon electrode (GCE). Owing to a large synergetic effect, ${ }^{26}$ electron transfer between BPA and the electrode surface was improved by $\mathrm{GO}-\mathrm{Fe}_{3} \mathrm{O}_{4}$, resulting in selective and stable sensing. As expected, the sensor showed superior analytical parameters against lab samples. Therefore, the prepared sensor was employed for selective and sensitive detection of BPA in real thermal receipt samples.

\footnotetext{
${ }^{a}$ Department of Chemical Engineering and Biotechnology, National Taipei University of Technology, No. 1, Section 3, Chung-Hsiao East Road, Taipei 106, Taiwan. E-mail: smchen78@ms15.hinet.net; Fax: +8862270 2523; Tel: +8862270 17147

${ }^{b}$ Chemistry Division, Center for General Education, Chang Gung University, Taoyuan, Taiwan. E-mail: blou@mail.cgu.edu.tw; Fax: +8863211 8700; Tel: +886 32118800 ${ }^{c}$ Department of Nuclear Medicine and Molecular Imaging Center, Chang Gung Memorial Hospital, Taoyuan, Taiwan

$\dagger$ Electronic supplementary information (ESI) available. See DOI: 10.1039/c8ra08017h

\$ These authors contributed equally.
}

\section{Experimental}

\subsection{Chemicals}

BPA, butyl acetate, and ethanol were purchased (see ESI, S1 $\dagger$ ) and used as received. Electrochemical studies were conducted using $0.1 \mathrm{M}$ phosphate buffer $(\mathrm{pH} 7)$ as the supporting 


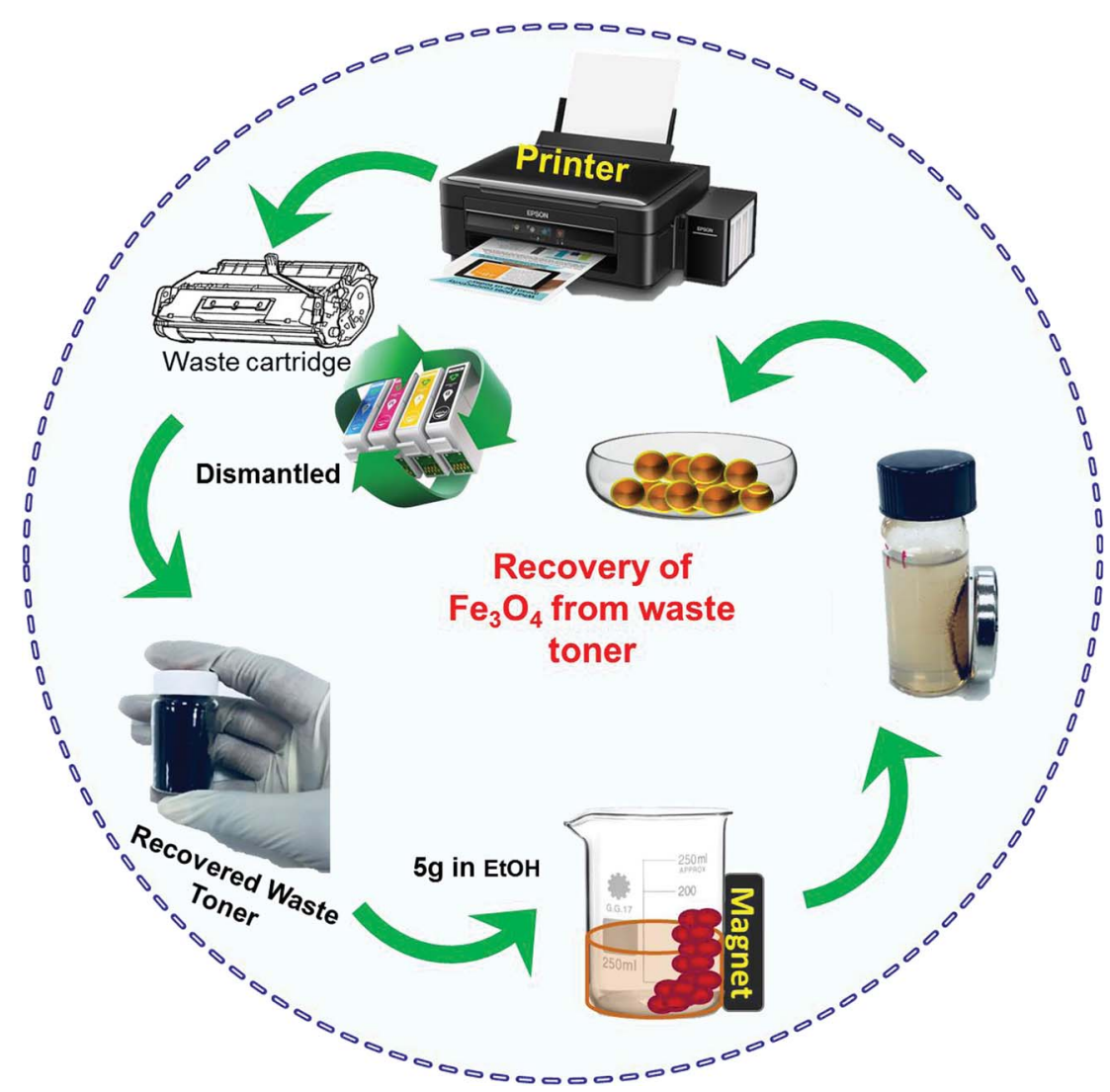

Scheme 1 Recovery procedure of $\mathrm{Fe}_{3} \mathrm{O}_{4}$ from the waste toner.

electrolyte. The preparation of electrolytes, chemical consumption, and equipment used are described in the ESI (S1†).

\subsection{Extraction and purification of $\mathrm{Fe}_{3} \mathrm{O}_{4}$}

Initially, discarded cartridges were dismantled to recover the waste toner inside (Scheme 1). As-obtained toner $(5 \mathrm{~g})$ was dissolved in ethanol $(50 \mathrm{~mL})$ in a beaker with a magnet attached to the side and stirred vigorously with a glass rod. When stirring was stopped, some material had settled near the magnet, while the rest remained moving in solution. The supernatant was decanted and the same stirring procedure was repeated with fresh solvent, followed by decanting again. The magnetically separated powder was collected, finely ground, dissolved in butyl acetate $(15 \mathrm{~mL})$, and stirred for $30 \mathrm{~min}$ to remove impurities inside the lumps of toner. The solution was centrifuged several times with ethanol and dried in an oven at $90^{\circ} \mathrm{C}$ for $7 \mathrm{~h}$. Finally, the resulting dried powder was calcined at $500{ }^{\circ} \mathrm{C}$ for $2 \mathrm{~h}$. The recovered material was placed under $5 \% \mathrm{H}_{2} / \mathrm{Ar}$ flowing at $40 \mathrm{~mL} \mathrm{~min}{ }^{-1}$ and heated from $50{ }^{\circ} \mathrm{C}$ to $500{ }^{\circ} \mathrm{C}$ at a rate of $10^{\circ} \mathrm{C} \mathrm{min}^{-1}$. The resulting powder was further characterized.

\subsection{Preparation of $\mathrm{GO}-\mathrm{Fe}_{3} \mathrm{O}_{4}$ composite}

To prepare the $\mathrm{GO}-\mathrm{Fe}_{3} \mathrm{O}_{4}$ composite, $\mathrm{Fe}_{3} \mathrm{O}_{4}(1 \mathrm{mg})$ was added to GO dispersion ( $2 \mathrm{~mL}, 1 \mathrm{mg} \mathrm{mL} \mathrm{mL}^{-1}$ ) in $45 \%$ ethanol and magnetically stirred for $15 \mathrm{~min}$. The resulting mixture was ultrasonicated for another $15 \mathrm{~min}$, which ensured sufficient interfacial self-assembly of negative GO sheets on positively charged $\mathrm{Fe}_{3} \mathrm{O}_{4}$ via electrostatic interactions, resulting in a stable network of $\mathrm{Fe}_{3} \mathrm{O}_{4}$ encapsulated by thin layers of GO.

\section{Results and discussion}

\subsection{Structural and elemental characterization}

Morphological and structural information for the recovered $\mathrm{Fe}_{3} \mathrm{O}_{4}$, graphene oxide, and $\mathrm{GO}-\mathrm{Fe}_{3} \mathrm{O}_{4}$ composite were obtained using FE-SEM. The size of recovered $\mathrm{Fe}_{3} \mathrm{O}_{4}$ was determined using the particle size distribution plot (Fig. S4 $\dagger$ ) and scaled to a mean size of $109 \mathrm{~nm}$, as shown in Fig. 1A. Fig. 1B shows the thin GO sheets. Our previously reported procedure was used to prepare GO, ${ }^{27}$ which was then ultrasonicated with the recovered $\mathrm{Fe}_{3} \mathrm{O}_{4}$ nanoparticles to obtain the composite, as shown in Fig. 1C and D, with different magnifications. The fine thin GO sheets enveloped each of the recovered spheres, as also confirmed using TEM (Fig. 2A and B). Elemental detection of the recovered ferrous material was conducted to determine the presence of impurities, as detailed in the ESI ( $\mathrm{S} 2 \dagger)$.

Fig. 3A shows the survey spectrum of the $\mathrm{GO}-\mathrm{Fe}_{3} \mathrm{O}_{4}$ composite. Characteristic O 1s, C 1s, Fe 2p, and Fe 3p peaks were identified. The drastic increase in the $\mathrm{O} 1 \mathrm{~s}$ and $\mathrm{C} 1 \mathrm{~s}$ intensities was due to the presence of graphene oxide, which covered the surface of recovered $\mathrm{Fe}_{3} \mathrm{O}_{4}$. Fig. 3B shows the Fe 2p spectrum of $\mathrm{GO}-\mathrm{Fe}_{3} \mathrm{O}_{4}$, in which the peaks at 710.2 and $724.9 \mathrm{eV}$ 

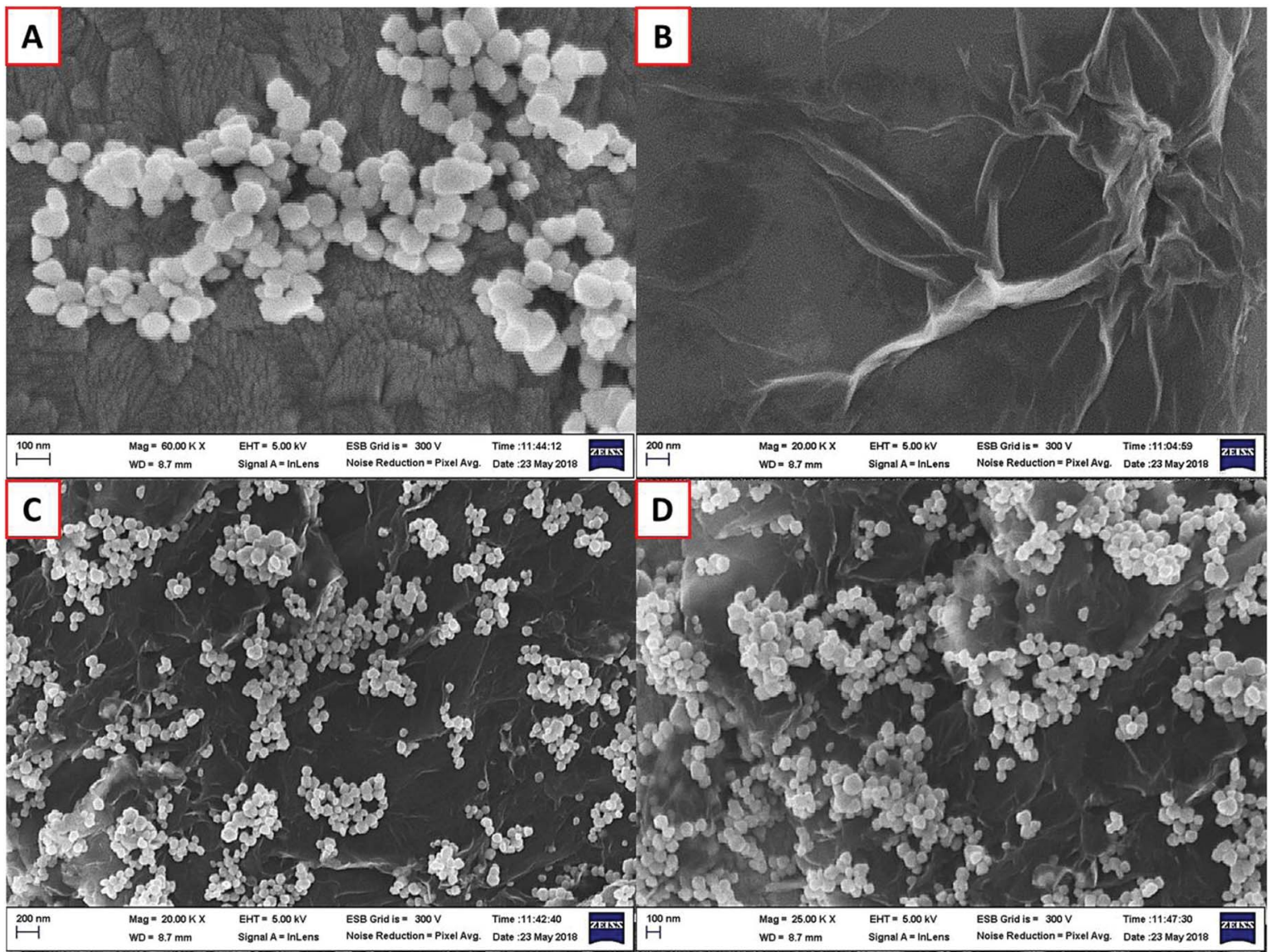

Fig. 1 FE-SEM images of $\mathrm{Fe}_{3} \mathrm{O}_{4}(\mathrm{~A})$ and $\mathrm{GO}(\mathrm{B})$, and $\mathrm{GO}-\mathrm{Fe}_{3} \mathrm{O}_{4}(\mathrm{C}$ and $\mathrm{D})$.

are assigned to $\mathrm{Fe} 2 \mathrm{p}_{3 / 2}$ and $\mathrm{Fe} 2 \mathrm{p}_{1 / 2}$, respectively, which confirmed that the particles recovered from waste toner were $\mathrm{Fe}_{3} \mathrm{O}_{4}$ nanoparticles..$^{28}$ The small peak at $720 \mathrm{eV}$, found between those of $\mathrm{Fe} 2 \mathrm{p}_{3 / 2}$ and $\mathrm{Fe} 2 \mathrm{p}_{1 / 2}$, indicated the presence of smaller amounts of $\mathrm{Fe}_{2} \mathrm{O}_{3} \cdot{ }^{28}$ The inset of Fig. 3B shows that the $\mathrm{Fe} 2 \mathrm{p}_{3 / 2}$ peak was well fitted with two deconvoluted peaks at around
$712 \mathrm{eV}$ and $710 \mathrm{eV}$, which were attributed to $\mathrm{Fe}^{3+}$ (major) and $\mathrm{Fe}^{2+}$ (minor), respectively. ${ }^{29}$ Therefore, the presence of $\mathrm{Fe}_{3} \mathrm{O}_{4}$ was confirmed by XPS analysis.

The XRD pattern of recovered $\mathrm{Fe}_{3} \mathrm{O}_{4}$ nanoparticles is shown in Fig. $\mathrm{S} 3, \dagger$ which shows the characters of $\mathrm{Fe}_{3} \mathrm{O}_{4}$ nanoparticles with distinct crystallinity. Overall, the diffraction peaks

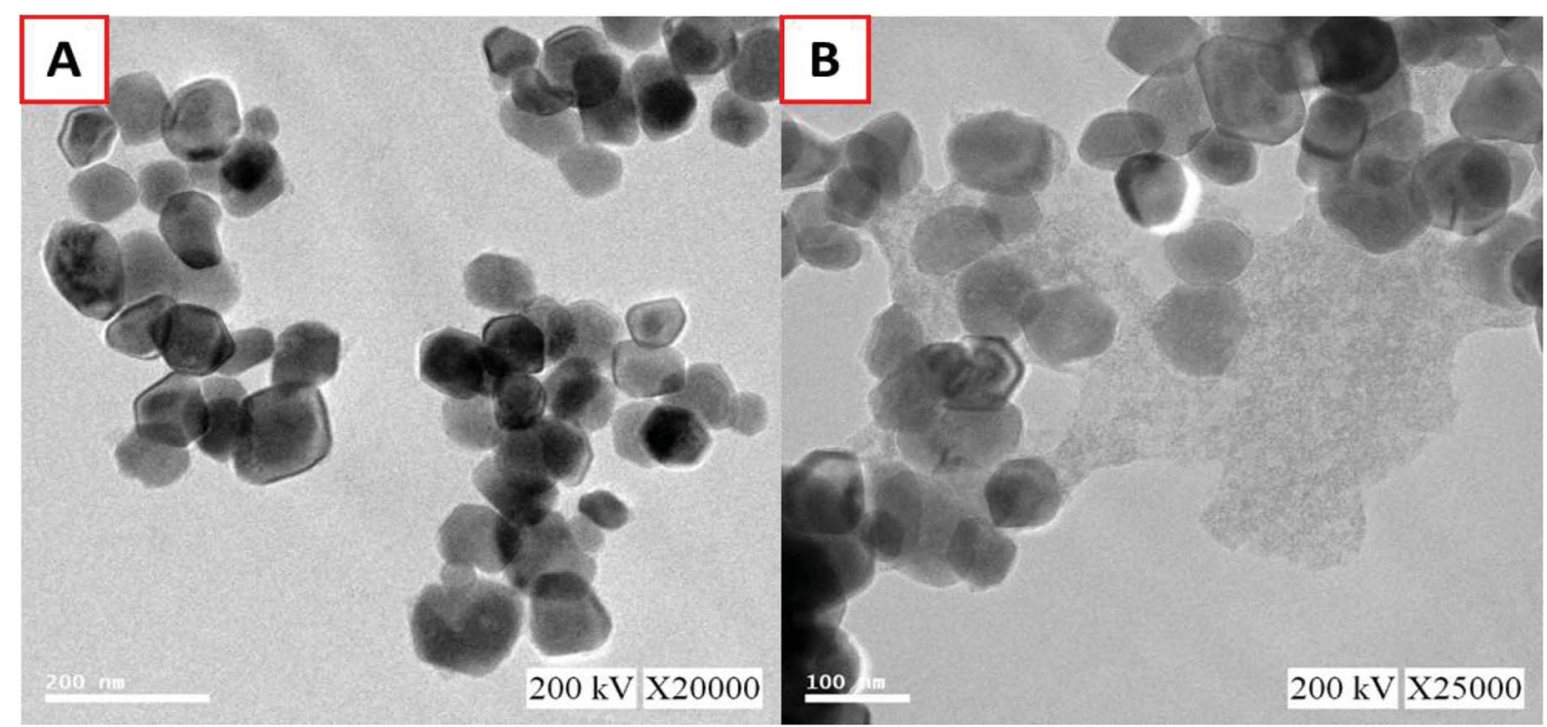

Fig. 2 TEM images of $\mathrm{Fe}_{3} \mathrm{O}_{4}(\mathrm{~A})$ and $\mathrm{GO}-\mathrm{Fe}_{3} \mathrm{O}_{4}$ (B). 

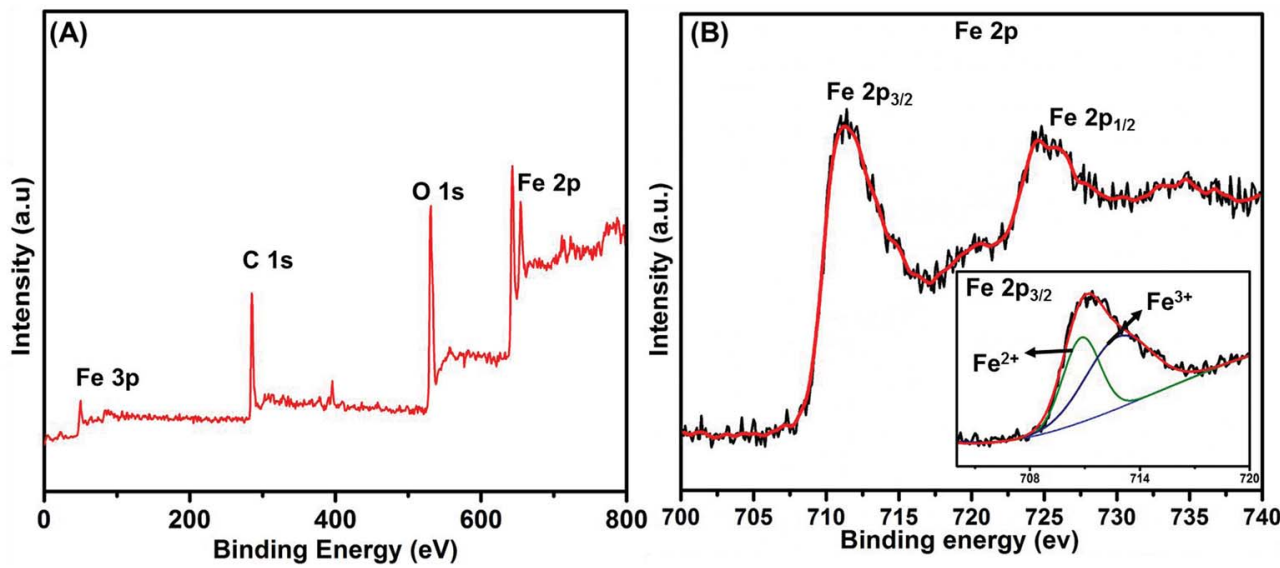

Fig. 3 (A) Survey spectrum of $\mathrm{Fe}_{3} \mathrm{O}_{4} / \mathrm{GO}$, and (B) high-resolution spectrum of $\mathrm{Fe} 2 \mathrm{p}$ (inset: deconvoluted peaks of $\mathrm{Fe} 2 \mathrm{p}_{3 / 2}$ ).

correlated well with characteristic peaks of the $\mathrm{Fe}_{3} \mathrm{O}_{4}$ inverse spinel structure (PCPDFWIN v.2.02, PDF no. 89-0691). No obvious impurity peaks were found in the diffraction pattern.

Fig. 4A and $\mathrm{B}$ show the BET surface analysis of $\mathrm{Fe}_{3} \mathrm{O}_{4}$ and $\mathrm{GO}-\mathrm{Fe}_{3} \mathrm{O}_{4}$. Both materials had type 1 isotherms. The BET surface areas were found to be $4.3924 \mathrm{~m}^{2} \mathrm{~g}^{-1}$ for $\mathrm{Fe}_{3} \mathrm{O}_{4}$ nanoparticles and $25.2086 \mathrm{~m}^{2} \mathrm{~g}^{-1}$ for $\mathrm{GO}-\mathrm{Fe}_{3} \mathrm{O}_{4}$.

\subsection{Electrocatalytic properties of $\mathrm{Fe}_{3} \mathrm{O}_{4^{-}}$and $\mathrm{GO}-\mathrm{Fe}_{3} \mathrm{O}_{4^{-}}$ modified GCEs}

The electrochemical kinetics of different electrodes were investigated using the $\left(\left[\mathrm{Fe}(\mathrm{CN})_{6}\right]^{3-/ 4-}\right)$ redox probe. Fig. 5A shows the CVs of unmodified GCE, GO/GCE, $\mathrm{Fe}_{3} \mathrm{O}_{4} / \mathrm{GCE}$, and $\mathrm{Fe}_{3} \mathrm{O}_{4} / \mathrm{GO} / \mathrm{GCE}$ containing $0.05 \mathrm{M}$ of $[\mathrm{Fe}(\mathrm{CN}) 6]^{3-/ 4-}$ at a scan rate of $0.05 \mathrm{~V} \mathrm{~s}^{-1}$. Compared with the other modified electrodes $\mathrm{Fe}_{3} \mathrm{O}_{4} / \mathrm{GO} / \mathrm{GCE}$ showed an excellent redox peak, good electrochemical conductivity, and tolerable peak-to-peak potential separation $\left(\Delta E_{\mathrm{p}}\right)$. The calculated $\Delta E_{\mathrm{p}}$ values of bare GCE, GO/ GCE, $\mathrm{Fe}_{3} \mathrm{O}_{4} / \mathrm{GCE}$, and $\mathrm{Fe}_{3} \mathrm{O}_{4} / \mathrm{GO} / \mathrm{GCE}$ were 145, 123, 84, and $52 \mathrm{mV}$, respectively. The cathodic to anodic peak current ratio $\left(I_{\mathrm{p}_{\mathrm{c}}} / I_{\mathrm{P}_{\mathrm{a}}}\right)$ of $\mathrm{Fe}_{3} \mathrm{O}_{4} / \mathrm{GO} / \mathrm{GCE}$ was 0.98 , which is close to 1 , confirming that the reaction is reversible. Furthermore, the $I_{\mathrm{P}_{\mathrm{c}}} / I_{\mathrm{P}_{\mathrm{a}}}$ ratios of unmodified GCE, GO/GCE, and $\mathrm{Fe}_{3} \mathrm{O}_{4} / \mathrm{GCE}$ were 0.91, 0.93 , and 0.95 , respectively. The electroactive surface area (EASA) of the recovered material and its composites were measured using the Randles-Sevcik equation (eqn (1)). ${ }^{30,31}$ Meanwhile, by altering the scan rates, the kinetics in the $\left[\mathrm{Fe}(\mathrm{CN})_{6}\right]^{3-/ 4-}$ system were investigated (Fig. 5B).

$$
I_{\mathrm{p}}=2.69 \times 10^{5} n^{3 / 2} A D^{1 / 2} C v^{1 / 2}
$$

The EASA values of bare GCE, GO/GCE, $\mathrm{Fe}_{3} \mathrm{O}_{4} / \mathrm{GCE}$, and $\mathrm{Fe}_{3} \mathrm{O}_{4} / \mathrm{GO} / \mathrm{GCE}$ were calculated as $0.082,0.119,0.166$, and 0.193 $\mathrm{cm}^{2}$, respectively, from the slope of $I_{\mathrm{pa}} v s . v^{1 / 2}$. Furthermore, CV studies observed at different scan rates elucidated the pseudocapacity of $\mathrm{Fe}_{3} \mathrm{O}_{4} / \mathrm{GO} / \mathrm{GCE}$. The greater charge diffusion polarization of the recovered $\mathrm{Fe}_{3} \mathrm{O}_{4} / \mathrm{GO} / \mathrm{GCE}$ was indicated by the increased peak current.

\subsection{Voltammetric response of modified electrodes towards BPA}

The electrochemical sensing behavior of different modified electrodes towards BPA oxidation was evaluated in $0.1 \mathrm{M}$
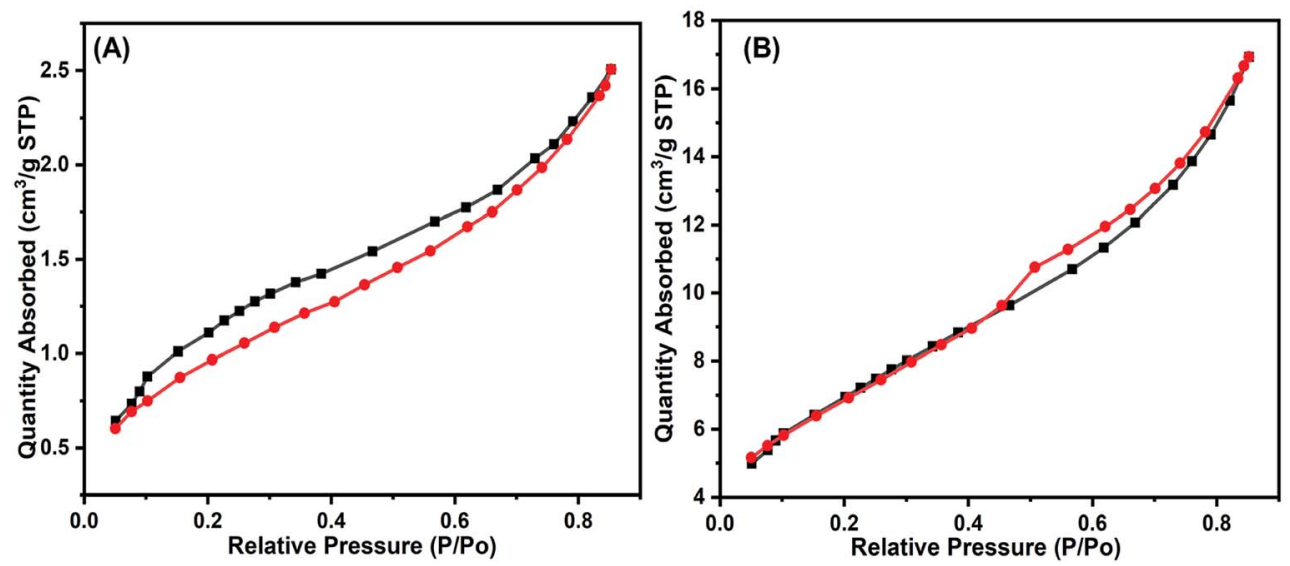

Fig. 4 BET surface analysis of $\mathrm{Fe}_{3} \mathrm{O}_{4}(\mathrm{~A})$ and $\mathrm{GO}-\mathrm{Fe}_{3} \mathrm{O}_{4}$ (B). 

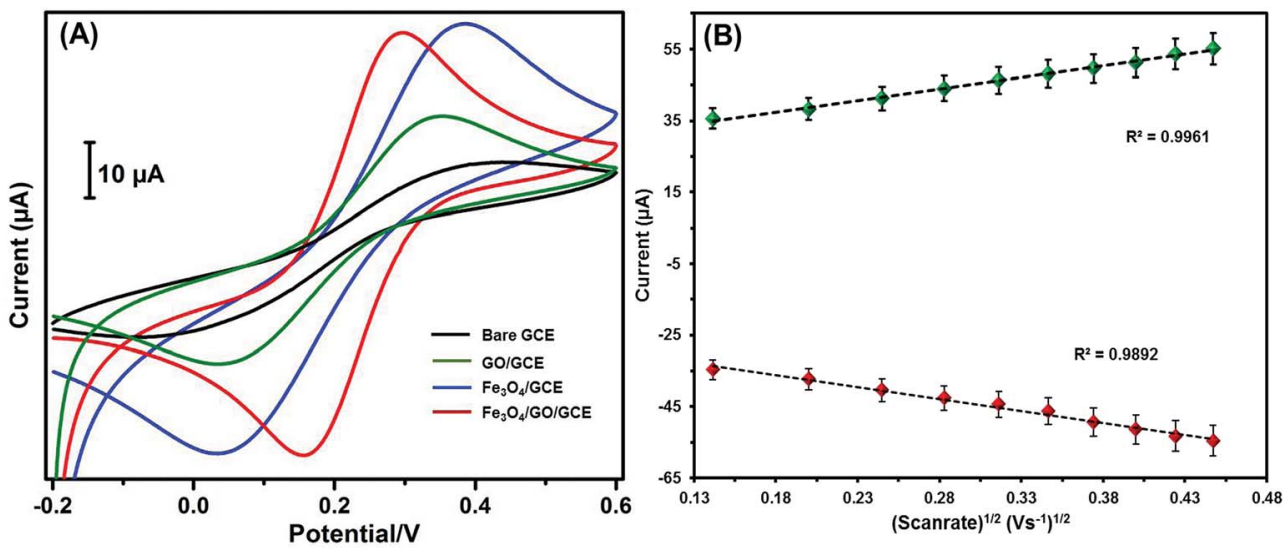

Fig. 5 (A) $\mathrm{CV}$ s of bare GCE, GO/GCE, $\mathrm{Fe}_{3} \mathrm{O}_{4} / \mathrm{GCE}$ and $\mathrm{Fe}_{3} \mathrm{O}_{4} / \mathrm{GO} / \mathrm{GCE}$ in $0.1 \mathrm{M} \mathrm{KCl}$ containing $5 \mathrm{mM}\left[\mathrm{Fe}(\mathrm{CN})_{6}\right]^{3-/ 4-}$, and $(\mathrm{B}) \mathrm{Fe} \mathrm{O}_{4} / \mathrm{GO} / \mathrm{GCE}$ calibration plot of $I_{p_{c}} / I_{p_{a}} v s . v^{1 / 2}$.

phosphate buffer solution (PBS) at a scan rate of $0.05 \mathrm{~V} \mathrm{~s}^{-1}$. Fig. $6 \mathrm{~A}$ shows the CVs of bare $\mathrm{GCE}, \mathrm{GO} / \mathrm{GCE}, \mathrm{Fe}_{3} \mathrm{O}_{4} / \mathrm{GCE}$, and $\mathrm{Fe}_{3} \mathrm{O}_{4} / \mathrm{GO} / \mathrm{GCE}$ with BPA $(50 \mu \mathrm{M})$ in $0.1 \mathrm{M}$ PBS. No oxidation peak current was observed for the unmodified GCE. Furthermore, the oxidation peak current value observed for $\mathrm{Fe}_{3} \mathrm{O}_{4} / \mathrm{GO} /$ GCE was notable among the other modified electrodes. This confirmed that the $\mathrm{Fe}_{3} \mathrm{O}_{4} / \mathrm{GO} / \mathrm{GCE}$ modified electrode had a higher peak current response and more capable active electron transmission movement than the other modified electrodes. A possible electrochemical oxidation mechanism of BPA is shown in eqn (2).

\subsection{Electrochemical performance of $\mathrm{Fe}_{3} \mathrm{O}_{4} / \mathrm{GO} / \mathrm{GCE}$ towards BPA}

Fig. 6C shows the CVs of $\mathrm{Fe}_{3} \mathrm{O}_{4} / \mathrm{GO} / \mathrm{GCE}$ obtained with increasing BPA concentration $(10-100 \mu \mathrm{M})$ at a scan rate of $0.05 \mathrm{~V} \mathrm{~s}^{-1}$ in $0.1 \mathrm{M}$ PBS. The outstanding oxidation peak current intensified with increasing BPA concentration. The linear plot of oxidation peak current vs. BPA concentration is shown in Fig. 6D. The linear regression equation was calculated to be $I_{\mathrm{pa}_{\mathrm{a}}}$ $(\mu \mathrm{A})=0.2278-0.3567 c(\mu \mathrm{M}), R^{2}=0.9964$.<smiles>CC(C)(C1=CCC(=O)C=C1)c1ccc(O)cc1</smiles>

\subsection{Effect of $\mathrm{pH}$ on $\mathrm{Fe}_{3} \mathrm{O}_{4} / \mathrm{GO} / \mathrm{GCE}$}

To determine the ideal $\mathrm{pH}$ for BPA detection by $\mathrm{Fe}_{3} \mathrm{O}_{4} / \mathrm{GO} / \mathrm{GCE}$, the electrochemical oxidation of BPA was conducted in different buffer solutions ( $\mathrm{pH} \mathrm{3-11)} \mathrm{and} \mathrm{the} \mathrm{changes} \mathrm{in} \mathrm{oxidation} \mathrm{peak}$ current with changing $\mathrm{pH}$ were plotted. Fig. 6B-blue shows the graphical plot for $\mathrm{pH}$ vs. obtained current, evidently showing the most intense oxidation peak current at $\mathrm{pH}$ 7. The linearity of BPA detection was confirmed by the peak potential $\left(E_{\mathrm{p}}\right)$ plot, as shown in Fig. 6B-green. The acquired slope value for BPA $(-53.2$ $\mathrm{mV}$ ) was near to the value mentioned in the Nernst equation, ${ }^{32}$ which confirmed that the same number of protons and electrons were involved in the reduction mechanism on $\mathrm{Fe}_{3} \mathrm{O}_{4} / \mathrm{GO} /$ GCE.
CVs were recorded for $\mathrm{Fe}_{3} \mathrm{O}_{4} / \mathrm{GO} / \mathrm{GCE}$ in $0.1 \mathrm{M}$ PBS containing BPA $(50 \mu \mathrm{M})$ at different scan rates $\left(20-200 \mathrm{mV} \mathrm{s}^{-1}\right)$, as shown in Fig. 6E. Increasing the scan rate resulted in a linear increase in the anodic and cathodic peak currents. The calibration plot of the square root of scan rate $v s$. oxidation peak current is shown in Fig. 6F. The linear regression equation was calculated as $I_{\mathrm{P}_{\mathrm{a}}}(\mu \mathrm{A})=38.838+3.7743$ and the correlation coefficient was 0.9982 , indicating that the reaction was a surface-confined process.

\subsection{Amperometric detection of BPA}

To define the analytical efficacy of $\mathrm{GO}-\mathrm{Fe}_{3} \mathrm{O}_{4}$, amperometric-it was executed for BPA detection. As shown in Fig. 7A, as the BPA concentration was increased from $0.025 \mu \mathrm{M}$ to $100 \mu \mathrm{M}$, the oxidation peak current increased linearly without any larger 

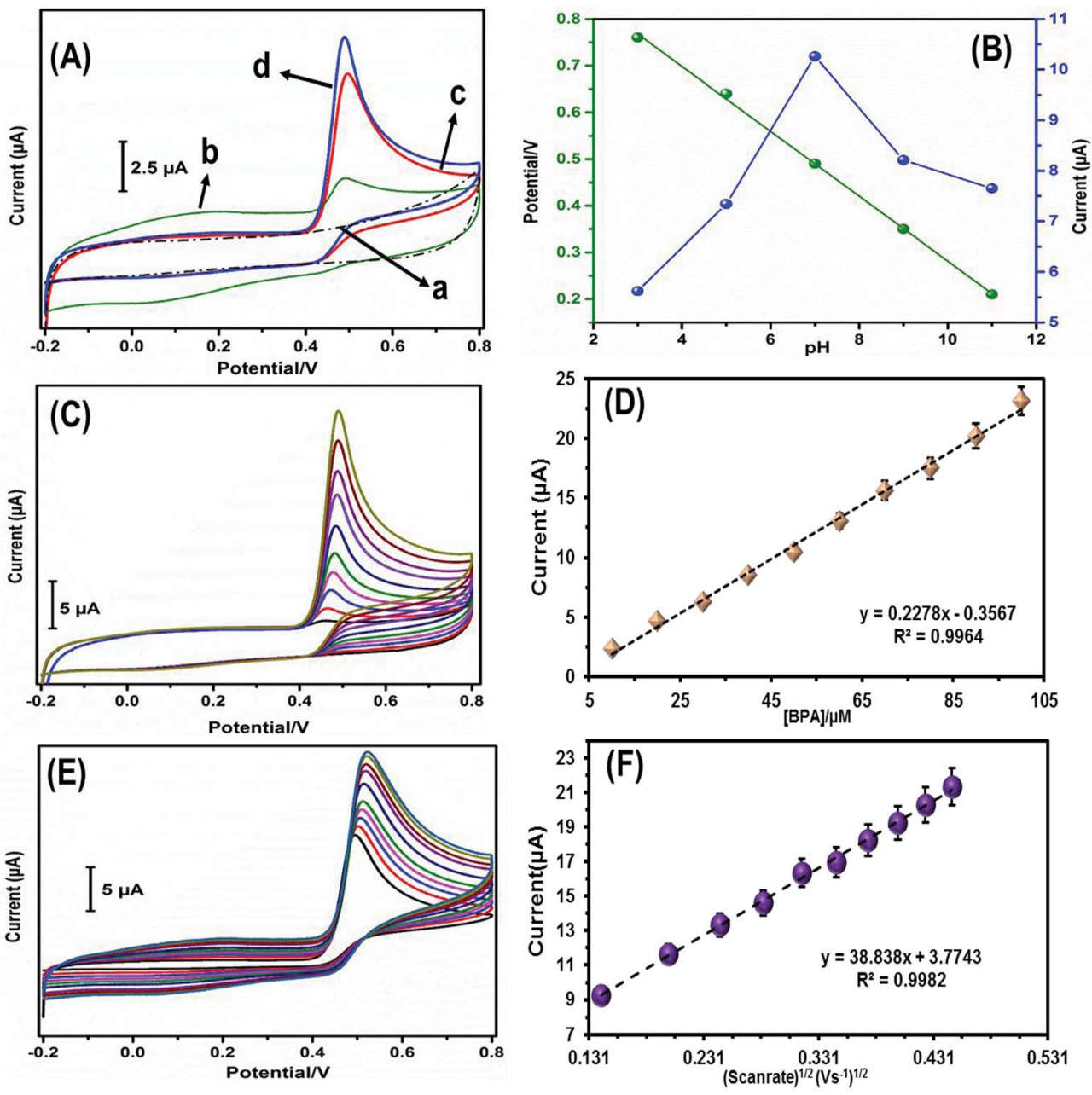

Fig. 6 (A) CVs of bare GCE (a), GO/GCE (b), $\mathrm{Fe}_{3} \mathrm{O}_{4} / \mathrm{GCE}$ (c), and $\mathrm{Fe}_{3} \mathrm{O}_{4} / \mathrm{GO} / \mathrm{GCE}$ (d) in $0.1 \mathrm{M}$ pH 7 containing $50 \mu \mathrm{M}$ of BPA. (B) The plot of different $\mathrm{pH}$ vs. potential (green) and different $\mathrm{pH}$ vs. current (blue) containing $50 \mu \mathrm{M}$ of BPA. (C) CVs obtained at $\mathrm{Fe} \mathrm{O}_{3} / \mathrm{GO} / \mathrm{GCE}$ containing BPA $(10 \mu \mathrm{M}$ to $100 \mu \mathrm{M})$ in $0.1 \mathrm{M} \mathrm{pH}$ 7. (D) Calibration plot of [BPA] $/ \mu \mathrm{M}$ vs. current ( $\mu \mathrm{A})$. (E) $\mathrm{CVs}$ obtained at Fe $\mathrm{O}_{4} / \mathrm{GO} / \mathrm{GCE}$ in $0.1 \mathrm{M} \mathrm{pH} 7 \mathrm{containing} 50$ $\mu \mathrm{M}$ of BPA at different scan rates $\left(20\right.$ to $\left.200 \mathrm{mV} \mathrm{s}^{-1}\right)$. (F) (Scan rate) $)^{1 / 2}\left(\mathrm{~V} \mathrm{~s}^{-1}\right)^{1 / 2} v$ s. peak currents $(\mu \mathrm{A})$.

vacillations (Fig. 7B). Therefore, $\mathrm{GO}-\mathrm{Fe}_{3} \mathrm{O}_{4}$ was suitable for the trace level detection of BPA. This yielded a wider linear range of $25 \mathrm{nM}$ to $782.75 \mu \mathrm{M}$, with a very low detection limit of $6.9 \mathrm{nM}$. The sensitivity towards BPA was calculated as $2.62238 \mu \mathrm{A} \mu \mathrm{M}^{-1}$ $\mathrm{cm}^{-2}$. Therefore, $\mathrm{GO}-\mathrm{Fe}_{3} \mathrm{O}_{4}$ has superior parameters, which are necessary for an effective sensor. Finally, the linear range and LOD were compared with previously reported BPA sensors (Table 1), with the $\mathrm{GO}-\mathrm{Fe}_{3} \mathrm{O}_{4}$ modified electrode showing excellent sensing properties toward BPA detection. As a control study, GO was fabricated onto a GCE instead of $\mathrm{GO}-\mathrm{Fe}_{3} \mathrm{O}_{4}$, and the amperometric study was performed. The results obtained for $\mathrm{GO}$ were compared with those of $\mathrm{GO}-\mathrm{Fe}_{3} \mathrm{O}_{4}$, as shown in Fig. S6A. $\dagger$ Fig. $\mathrm{S} 6 \mathrm{~B} \uparrow$ shows the linear plot of the pure GO modified electrode, with the linear range and limit of detection were calculated as 1-559 $\mu \mathrm{M}$ and $821.2 \mathrm{nM}$, respectively.

\subsection{BPA selectivity}

The BPA selectivity was measured using an amperometric technique in $0.1 \mathrm{M}$ PBS. To determine the selectivity of the GO-
$\mathrm{Fe}_{3} \mathrm{O}_{4}$ adapted electrode, interfering substances $(200 \mu \mathrm{M})$ were added in the presence of BPA $(50 \mu \mathrm{M})$, as shown in Fig. 7C. As a result, the interfering components showed a negligible current response and indicated satisfactory selectivity for BPA sensing.

\subsection{Repeatability, reproducibility, and durability}

The reusability of the prepared electrode was examined over ten uses in $0.1 \mathrm{M}$ PBS containing BPA $(50 \mu \mathrm{M})$ at $50 \mathrm{mV} \mathrm{s}^{-1}$, with the corresponding current responses plotted. After using ten times, the electrode showed $98.2 \%$ of its initial current response, indicating that $\mathrm{Fe}_{3} \mathrm{O}_{4} / \mathrm{GO} / \mathrm{GCE}$ has excellent reusability. In addition to investigating the repeatability, different $\mathrm{Fe}_{3} \mathrm{O}_{4} / \mathrm{GO} /$ GCE samples were freshly prepared and their CV responses recorded and response currents plotted, as shown in the ESI (S5†). The RSD was calculated as $3.17 \%$, which indicated that $\mathrm{Fe}_{3} \mathrm{O}_{4} / \mathrm{GO} / \mathrm{GCE}$ had excellent repeatability in BPA sensing. Furthermore, the sensor stability was monitored daily (Fig. 7D). After continuous use for 15 days, the sensor maintained 97.95\% 

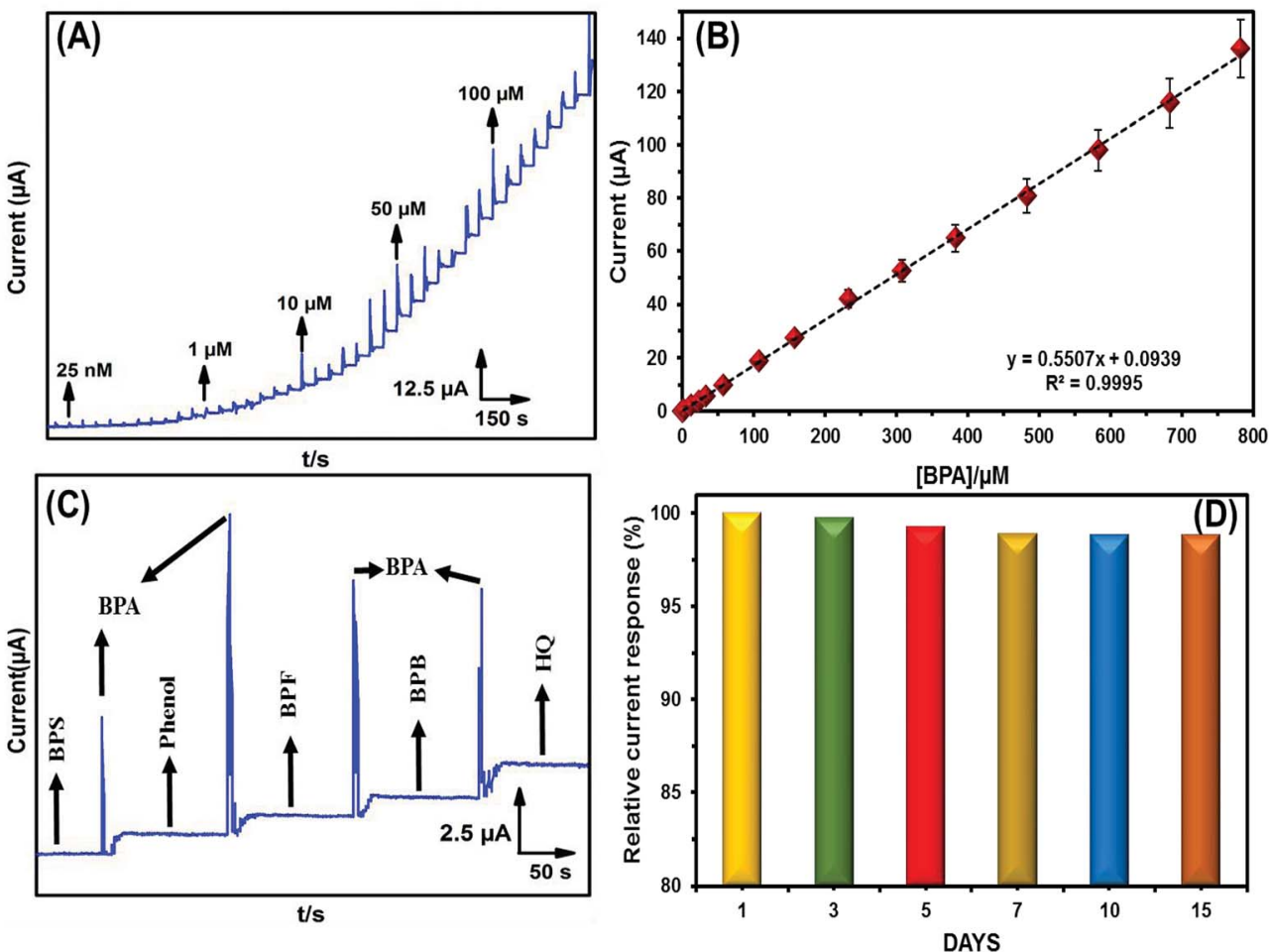

Fig. 7 (A) Amperometric response of $\mathrm{Fe}_{3} \mathrm{O}_{4} / \mathrm{GO}$ modified electrode for each sequential additions of $\mathrm{BPA}$ into $0.1 \mathrm{pH} 7$, the rotation speed $=$ $1200 \mathrm{rpm}$. (B) The plot of $[\mathrm{BPA}] / \mu \mathrm{M}$ vs. current $(\mu \mathrm{A})$. $E_{\mathrm{app}}=0.46 \mathrm{~V}$ (vs. $\left.\mathrm{Ag} / \mathrm{AgCl}\right)$. (C) Amperometric selective responses of $\mathrm{Fe}_{3} \mathrm{O}_{4}-\mathrm{GO}$ towards 50 $\mu \mathrm{M}$ of BPA. (D) Stability of the sensor as its continuous usage of 15 days.

Table 1 Comparison of analytical parameters obtained for $\mathrm{GO}-\mathrm{Fe}_{3} \mathrm{O}_{4}$ film-modified electrode toward BPA with previous reports

\begin{tabular}{|c|c|c|c|c|}
\hline Electrode & $\begin{array}{l}\text { LOD } \\
\text { (nM) }\end{array}$ & $\begin{array}{l}\text { Linear } \\
\text { range }(\mu \mathrm{M})\end{array}$ & Method & Reference \\
\hline${ }^{a}$ GN film electrode & 35 & $0.1-100$ & DPV & 33 \\
\hline $\begin{array}{l}{ }^{b} \mathrm{CS} /{ }^{c} \mathrm{MNPs}^{d}{ }^{d} \\
\mathrm{rGO} /{ }^{e} \mathrm{GCE}\end{array}$ & 16.7 & $0.06-11$ & DPV & 26 \\
\hline${ }^{b} \mathrm{CS}-\mathrm{Fe}_{3} \mathrm{O}_{4} /{ }^{d} \mathrm{GCE}$ & 8 & $0.05-30$ & DPV & 23 \\
\hline $\begin{array}{l}{ }_{\mathrm{MWCNTS} /} \mathrm{MW} \\
{ }^{g} \mathrm{PCV} /{ }^{e} \mathrm{GCE}\end{array}$ & 10 & $0.05-100$ & LSV & 34 \\
\hline${ }^{d}$ rGO-Ag $/{ }^{h}$ PLL & 540 & $1-80$ & DPV & 35 \\
\hline $\mathrm{Cu}_{2} \mathrm{O}-{ }^{d} \mathrm{rGO}$ & 53 & $0.1-80$ & AMP & 36 \\
\hline $\mathrm{Fe}_{3} \mathrm{O}_{4} / \mathrm{GO} / \mathrm{GCE}$ & 6.9 & $0.025-782.75$ & AMP & This work \\
\hline
\end{tabular}

${ }^{a} \mathrm{GN}$, graphite nanoparticles. ${ }^{b} \mathrm{CS}$, chitosan. ${ }^{c}$ MNPs, magnetic nanoparticles. ${ }^{d}$ rGO, reduced graphene oxide. ${ }^{e} \mathrm{GCE}$, glassy carbon electrode. ${ }^{f}$ MWCNT, multi-walled carbon nanotubes. ${ }^{g}$ PCV, poly crystal violet. ${ }^{h}$ PLL, poly-L-lysine.

of its initial response. From these results, $\mathrm{Fe}_{3} \mathrm{O}_{4} / \mathrm{GO} / \mathrm{GCE}$ showed superior efficacy toward BPA sensing.

\subsection{Real sample investigation}

The practicality of the equipped sensor was tested on thermal receipt samples collected from the various convenience stores, restaurants, and ATMs in Taiwan. The sample preparation procedures are explained under their classifications in Scheme 2. The BPA concentration levels found in the thermal receipts are shown in Table 2. A standardized HPLC-UV method was first used to detect the BPA levels in thermal receipts, then the developed sensor, $\mathrm{Fe}_{3} \mathrm{O}_{4} / \mathrm{GO} / \mathrm{GCE}$, was used to detect BPA in the same samples. Finally, the results obtained by the developed electrode were compared with those of the standardized method (HPLC-UV). The found and recovered contents of the real samples are shown in Table 3. The "Added" category in Table 3 denotes the BPA levels in the thermal receipts confirmed by HPLC.

\subsection{Migration technique}

For the migration technique, the sample was prepared as follows. Initially, each thermal receipts was gently rubbed with a separate kimwipe lightly dampened with methanol. These kimwipes were placed in corresponding vials containing methanol $(20 \mathrm{~mL})$. After $2 \mathrm{~h}$, the solution was collected, filtered through a nylon filter, and transferred into a sample vial. Finally, the solution was taken for HPLC analysis. For the comparison study, the same samples were subjected to the amperometric technique.

\subsection{Digestion technique}

Samples for digestion analysis were prepared by cutting the thermal receipts into small pieces and placing these pieces in separate vials containing methanol $(20 \mathrm{~mL})$. The samples were left undisturbed for $2 \mathrm{~h}$, then filtered through the nylon filter, and transferred into sample vials. The final solutions were subjected to HPLC and amperometric analyses. 


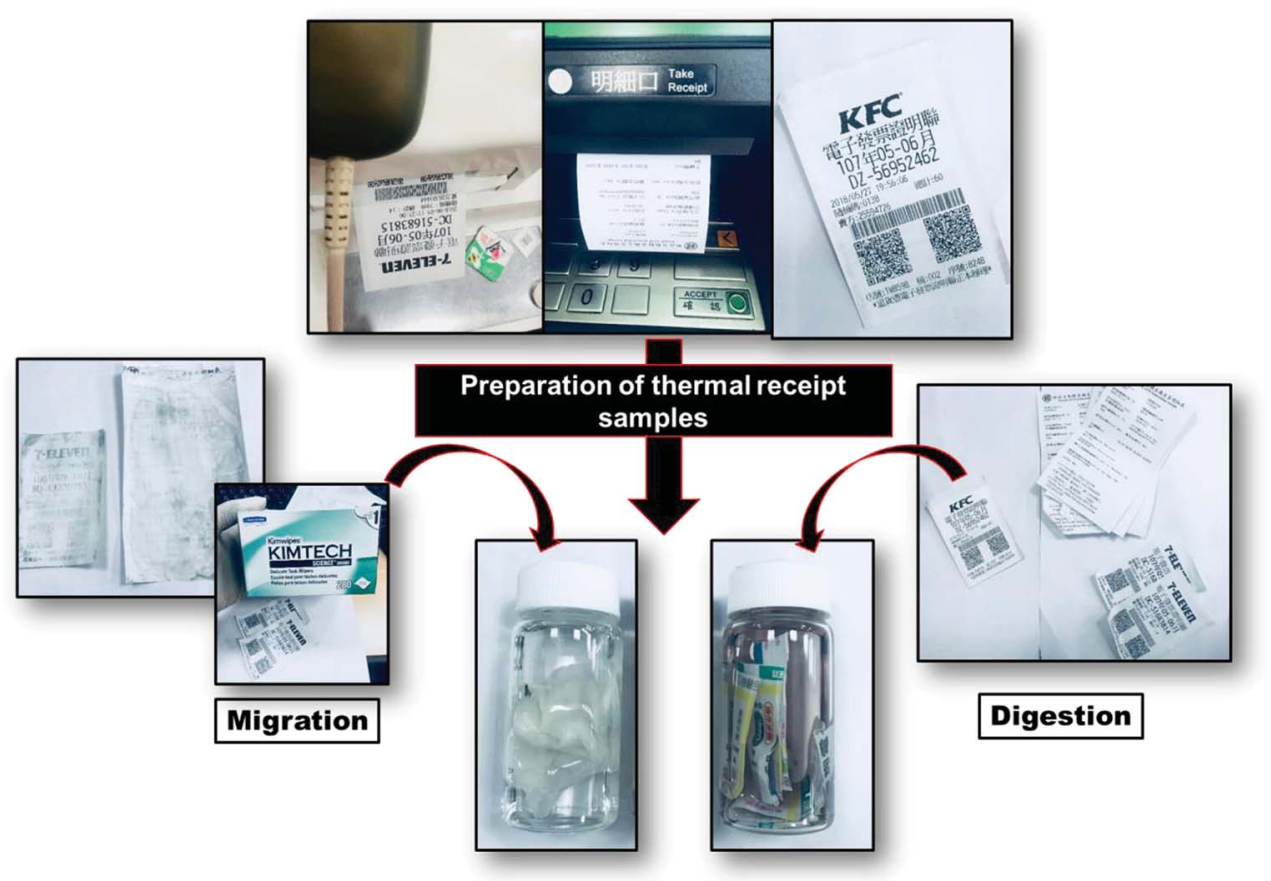

Scheme 2 Preparation procedure of thermal receipt samples.

Table $2 \mathrm{BPA}^{a}$

\begin{tabular}{lcc}
\hline & HPLC-UV & \\
\cline { 2 - 3 } Thermal receipts & Migration $\left(\mathrm{ng} \mathrm{mL}^{-1}\right)$ & ${\text { Digestion }\left(\mathrm{ng} \mathrm{mL}^{-1}\right)}$ \\
\hline Convenience store-1 & 4.52 & 6.26 \\
Convenience store-2 & 5.96 & 7.5 \\
Convenience store-3 & 5.02 & 6.49 \\
Restaurant-1 & 12.09 & 14.56 \\
Restaurant-2 & 9.25 & 11.62 \\
Restaurant-3 & 10.36 & 12.41 \\
ATM receipts & $\mathrm{ND}$ & $\mathrm{ND}$ \\
${ }^{a}$ Concentration levels in thermal receipts. & &
\end{tabular}

Table 3 Comparison of BPA detection in thermal receipts using the developed $\mathrm{Fe}_{3} \mathrm{O}_{4} / \mathrm{GO} / \mathrm{GCE}$ (found) and an HPLC method (added)

\begin{tabular}{llllll}
\hline Thermal receipts & Added $(\mu \mathrm{M})$ & Found $(\mu \mathrm{M})$ & Relative error $(\%)$ & ${ }^{a}$ RSD $(\%)$ & Average recovery $(\%)$ \\
\hline Convenience store-1 & 0.0198 & 0.0191 & 3.53 & 3.97 & 96.44 \\
Convenience store-2 & 0.022 & 0.0215 & 2.72 & 3.42 & 97.72 \\
Convenience store-3 & 0.028 & 0.0269 & 3.92 & 3.11 & 96.07 \\
Restaurant-1 & 0.063 & 0.0619 & 1.07 & 2.63 & 98.25 \\
Restaurant-2 & 0.05 & 0.0484 & 4.02 & 3.51 & 96.8 \\
Restaurant-3 & 0.054 & 0.0529 & 2.03 & 97.96
\end{tabular}

${ }^{a}$ Related standard deviation of three independent experiments.

\section{Conclusions}

In brief, $\mathrm{Fe}_{3} \mathrm{O}_{4}$ nanoparticles were prepared from waste toner by magnetic separation and thermal treatment. The recovered
$\mathrm{Fe}_{3} \mathrm{O}_{4}$ nanoparticles were sonicated with graphene oxide nanosheets to obtain a $\mathrm{GO}-\mathrm{Fe}_{3} \mathrm{O}_{4}$ composite. The structural, morphological, and electrochemical properties of the prepared nanocomposite were confirmed using FE-SEM, XPS, EDX, and 
voltammetric analysis. The recovered material was then fabricated onto a glassy carbon electrode and evaluated for BPA sensing, exhibiting outstanding electrocatalytic properties. As a BPA sensor, GO- $\mathrm{Fe}_{3} \mathrm{O}_{4}$ exhibited a very low detection limit of $6.9 \mathrm{nM}$ with a wider linear range of $25 \mathrm{nM}$ to $782.75 \mu \mathrm{M}$. This beneficial and reliable methodology for $\mathrm{Fe}_{3} \mathrm{O}_{4}$ recovery could be effective and economic for wide-scale ferrous production, and used in sensor development for the detection of hazardous BPA in thermal receipts.

\section{Conflicts of interest}

The authors declare no conflicts of interest.

\section{Acknowledgements}

The authors gratefully acknowledge financial support from the Ministry of Science and Technology, Taiwan (MOST 107-2221-E182-021 and MOST 106-2113-M-027-003). B.S. Lou also acknowledges financial support from the Chung Gung Memorial Hospital (BMRP 280).

\section{References}

1 J. Cui and L. Zhang, J. Hazard. Mater., 2008, 158, 228-256.

2 R. Widmer, H. Oswald-Krapf, D. Sinha-Khetriwal, M. Schnellmann and H. Böni, Environ. Impact Assess. Rev., 2005, 25, 436-458.

3 B. H. Robinson, Sci. Total Environ., 2009, 408, 183-191.

4 E. Sundin and H. M. Lee, in Design for innovative value towards a sustainable society, Springer, 2012, pp. 552-557.

5 H.-Y. Kang, Y.-S. Jun, Y.-C. Kim and H.-J. Jo, Procedia CIRP, 2016, 40, 280-284.

6 V. Gaikwad, U. Kumar, F. Pahlevani, A. Piadasa and V. Sahajwalla, ACS Sustainable Chem. Eng., 2017, 5, 1154311550.

7 D. Wang, Z. Cai, G. Jiang, A. Leung, M. H. Wong and W. K. Wong, Chemosphere, 2005, 60, 810-816.

8 T. Yamamoto and A. Yasuhara, Chemosphere, 1999, 38, 25692576.

9 K. Moriyama, T. Tagami, T. Akamizu, T. Usui, M. Saijo, N. Kanamoto, Y. Hataya, A. Shimatsu, H. Kuzuya and K. Nakao, J. Clin. Endocrinol. Metab., 2002, 87, 5185-5190.

10 R. T. Zoeller, R. Bansal and C. Parris, Endocrinology, 2005, 146, 607-612.

11 W. Zhou, J. Liu, L. Liao, S. Han and J. Liu, Mol. Cell. Endocrinol., 2008, 283, 12-18.

12 R. P. Sharma, M. Schuhmacher and V. Kumar, Sci. Total Environ., 2018, 624, 55-68.

13 F. S. Vom Saal, P. S. Cooke, D. L. Buchanan, P. Palanza, K. A. Thayer, S. C. Nagel, S. Parmigiani and W. V. Welshons, Toxicol. Ind. Health, 1998, 14, 239-260.
14 K. L. Howdeshell, A. K. Hotchkiss, K. A. Thayer, J. G. Vandenbergh and F. S. Vom Saal, Nature, 1999, 401, 763. 15 M. Aydoğan, A. Korkmaz, N. Barlas and D. Kolankaya, Toxicology, 2008, 249, 35-39.

16 H. Kabuto, M. Amakawa and T. Shishibori, J. Life Sci., 2004, 74, 2931-2940.

17 M. Kundakovic, K. Gudsnuk, B. Franks, J. Madrid, R. L. Miller, F. P. Perera and F. A. Champagne, Proc. Natl. Acad. Sci. U. S. A., 2013, 110, 9956-9961.

18 J. T. Wolstenholme, M. Edwards, S. R. Shetty, J. D. Gatewood, J. A. Taylor, E. F. Rissman and J. J. Connelly, Endocrinology, 2012, 153, 3828-3838.

19 C. Liao, F. Liu and K. Kannan, Environ. Sci. Technol., 2012, 46, 6515-6522.

20 S. Biedermann, P. Tschudin and K. Grob, Anal. Bioanal. Chem., 2010, 398, 571-576.

21 C. Liao and K. Kannan, Environ. Sci. Technol., 2011, 45, 93729379.

22 E. Union, Official Journal of the European Union, 2009, 5, 2009.

23 C. Yu, L. Gou, X. Zhou, N. Bao and H. Gu, Electrochim. Acta, 2011, 56, 9056-9063.

24 M. A. Subhan, P. C. Saha, M. Alam, A. M. Asiri, M. Al-Mamun and M. M. Rahman, J. Environ. Chem. Eng., 2018, 6, 13961403.

25 H. Fan, Y. Li, D. Wu, H. Ma, K. Mao, D. Fan, B. Du, H. Li and Q. Wei, Anal. Chim. Acta, 2012, 711, 24-28.

26 Y. Zhang, Y. Cheng, Y. Zhou, B. Li, W. Gu, X. Shi and Y. Xian, Talanta, 2013, 107, 211-218.

27 S. Kogularasu, M. Govindasamy, S.-M. Chen, M. Akilarasan and V. Mani, Sens. Actuators, B, 2017, 253, 773-783.

28 S. Saha, M. Jana, P. Samanta, N. C. Murmu, N. H. Kim, T. Kuila and J. H. Lee, RSC Adv., 2014, 4, 44777-44785.

29 F. Han, L. Ma, Q. Sun, C. Lei and A. Lu, Nano Res., 2014, 7, 1706-1717.

30 K. Ngamchuea, S. Eloul, K. Tschulik and R. G. Compton, J. Solid State Electrochem., 2014, 18, 3251-3257.

31 X. Wang, A. Sumboja, M. Lin, J. Yan and P. S. Lee, Nanoscale, 2012, 4, 7266-7272.

32 M. M. Walczak, D. A. Dryer, D. D. Jacobson, M. G. Foss and N. T. Flynn, J. Chem. Educ., 1997, 74, 1195.

33 X. Dong, X. Qi, N. Liu, Y. Yang and Y. Piao, Sensors, 2017, 17, 836.

34 W. Wang, J. Tang, S. Zheng, X. Ma, J. Zhu, F. Li and J. Wang, Food Anal. Methods, 2017, 10, 3815-3824.

35 Y. Li, H. Wang, B. Yan and H. Zhang, J. Electroanal. Chem., 2017, 805, 39-46.

36 R. Shi, J. Liang, Z. Zhao, A. Liu and Y. Tian, Talanta, 2017, 169, 37-43. 